\title{
HET BEDRIJFSBELEID
}

\author{
door H. Reinoud
}

\section{\$1. Inleiding}

De behoefte aan bezinning op de verschijnselen verband houdende met het besturen en functioneren van het bedrijf is in de laatste decenniën door verschillende oorzaken aanmerkelijk groter geworden. Een groep van problemen, die daarbij vooral de aandacht trekken, heeft betrekking op de hoogste leiding in en van de bedrijven. Aan een bijzonder onderwerp daaruit, nl. het bedrijfsbeleid, zijn onderstaande beschouwingen gewijd. De uitdrukkingen hoogste of centrale leiding ${ }^{1}$ ) worden daarbij als synoniemen gezien, terwijl zij voorshands als een ongedeeld begrip worden gehanteerd.

Beleid kan gezien worden als het aspect of de functie van de leiding, in het bijzonder van de hoogste leiding, dat zich richt op de basisdoelstellingen, - gedragslijnen en - directieven van het bedrijf. Beleid wordt in de Angelsaksische landen aangeduid met policy (policy formulation, policy making, policy decision, e.d.). Men zou in onze taal ook zonder bezwaar het woord bedrijfspolitiek kunnen gebruiken.

Aanvankelijk ${ }^{2}$ ) heb ik aan dit laatste woord de voorkeur gegeven, omdat beleid verschillende betekenissen kan hebben; het betekent o.a. ook overleg, bedachtzaamheid, omzichtigheid, e.d. Aangezien evenwel ook het woord politiek die inhoud kan hebben en het woord bedrijfsbeleid al enigermate ingeburgerd is geraakt, gebruik ik thans de uitdrukking bedrijfsbeleid met als synoniem bedrijfspolitiek.

Terwijl voor de eerste wereldoorlog in de praktijk van de zgn. wetenschappelijke bedrijfsleiding het accent sterk op uitvoeringsaspecten lag, is tussen de beide wereldoorlogen daarnevens meer aandacht gekomen voor problemen met betrekking tot de bedrijfsleiding. ${ }^{3}$ ) Daarop betrekking hebbende beschouwingen groepeerden zich rond begrippen als constitueren, plannen, dirigeren, controleren, leiding en uitvoering, enz. Verhandelingen over bedrijfsbeleid of policy in de zin van de onderhavige beschouwingen zal men daarbij echter vrijwel nooit aantreffen, zelfs de woorden bedrijfsbeleid of policy komen in die tijd weinig voor. Thans is er bijna geen spreker of schrijver over bedrijfsleiding meer, of hij gebruikt op de een of andere wijze de uitdrukking beleid of policy. In tal van Angelsaksische leerboeken ${ }^{4}$ ) op het gebied van „business administration" komt een hoofdstuk of passage voor over policy, hetgeen evenwel allerminst wil zeggen dat het betreffende onderwerp nu ook duidelijk uit de doeken is gekomen. Dit is ook be-

\footnotetext{
1) Aan het woord „topleiding", vertaling van het Engelse "topmanagement", wordt in de literatuur òf dezelfde betekenis als hoogste en centrale leiding toegekend, of wel het omvat een grotere groep functionarissen. Holden, Fish en Smith, "Top-management organization and control" (New York 1941), bijv. begrijpen onder topmanagement: „a) board of directors, b) general management, c) divisional management."

$\left.{ }^{2}\right)$ In voordrachten voor het Studiecentrum voor Bedrijfsbeleid begonnen in 1954.

3) Ik heb dit iets uitvoeriger toegelicht in mijn artikel "Een studie over een leider in actie" in het M.A.B. van december $1955, \$ 1$.

4) Na het schrijven van dit artikel is dezer dagen het boek verschenen van Prof. Dr H. J. van der Schroeff, "Leiding en organisatie van het bedrijf", waarin een overzichtelijk hoofdstuk aan het bedrijfsbeleid is gewijd.

Voordien heeft Prof. Dr J. F. Haccoû een aantal opmerkingen over bedrijfsbeleid gemaakt in "Some fundamental problems of policy formation and organisation in the commercial field", Leiden 1957.
} 
zwaarlijk mogelijk, omdat het nog zo nieuw is en er weinig wetenschappelijke verkenning en onderzoek terzake is verricht. Wel blijkt uit allerlei onderzoeken van organisatieadviseurs en sociaalwetenschappelijke deskundigen hoe uitermate belangrijk de betreffende materie voor een doelmatig bedrijfsbestuur is. Deze onderzoeken geven belangrijke aanwijzingen, maar zij kunnen niet in de plaats treden van rechtstreeks en uitsluitend op de vraagstukken van beleidsvorming gerichte wetenschappelijke research.

\section{De behoefte aan beleidsconcentratie}

De belangstelling voor het bedrijfsbeleid is niet toevallig. Zij houdt verband met de toenemende gecompliceerdheid van het besturen der bedrijven en de overbezetting van de topleiders. Daardoor wordt de behoefte en noodzaak gevoeld om orde te scheppen in de overstelpende hoeveelheid vraagstukken, waarvoor de topleiding van een bedrijf zich gesteld ziet, en om daarbij op een andere wijze dan tot nu toe veelal gebruikelijk het essentiële van het relatief minder essentiële in haar functie en taak te onderscheiden en voor zoveel mogelijk te scheiden.

Bedrijfsleiders ervaren, dat zij herhaaldelijk gesteld worden voor het nemen van besluiten over aangelegenheden, die eigenlijk reeds lang te voren in een veel algemener kader en veel principiëler bestudeerd hadden moeten worden en dat zij niet toekomen aan het uitstippelen van een duidelijke gedragslijn voor zichzelf en voor hun ondergeschikten.

In zijn bekende studie over de bezetting en werkmethoden van bedrijfsleiders „Executive Behaviour" merkt Sune Carlson op, dat ,when asked what particular part of their duties the executives themselves regarded as neglected, they almost without exception answered the long-range planning of their business". ${ }^{5}$ )

Bij zorgvuldige waarneming blijkt het aantal activiteiten, waaromtrent een zorgvuldige koersbepaling zou moeten geschieden, bijzonder groot te zijn. Om er slechts enige te noemen: uitgebreid of beperkt artikelenassortiment, hoever te gaan met het aandeel in een oligopolistische markt met het oog op mogelijke reacties van overheid en publiek, zelf winkels in de detailhandel exploiteren of zich te dien aanzien onthouden, welke soort reclame, welke produktiepolitiek, uitbesteding of niet, samenwerking met anderen of niet en zo ja ten aanzien van welke activiteiten, welke vormen van financiering, verhouding winstinhouding en -uitkering, eigen computer of deelneming in een computercentrum, al dan niet fabricage van nieuwe produkten met het risico bestaande afnemers van daarop betrekking hebbende onderdelen te frusteren, welke wijze van systematische kadervorming en interne organisatie, welke vormen van geografische decentralisatie, welk speurwerk en welk evenwicht tussen speurwerk en ontwikkeling, de expansie afremmen of niet, vaststelling investeringsprioriteiten, studie van de gevolgen van de E.E.G., enz., enz.

Houdt men in een grootbedrijf een inventarisatie van de zeer belangrijke beleidsonderwerpen, dan wordt men verrast door het aantal, dat vaak de honderden overschrijdt. Sommige schrijvers hebben getracht het algemene karakter van

5) Sune Carlson, "Executive Behaviour", Stockholm 1951, blz. 106-107.

Ook in de publicatie van Mr H. Luijk, ,Waar blijft de tijd van de directeur?", zijn geen concrete aanwijzingen over de tijdsbesteding voor beleid op lange termijn te vinden. Ook diens studie doet echter vermoeden, dat deze in de onderzochte gevallen gering was.

m a b blz. 251 
deze onderwerpen of de instelling en beginselen die er aan ten grondslag liggen te benaderen, zoals bijv. W. H. Newman ${ }^{6}$ ), die terzake het volgende overzicht geeft:

A. What place or niche does the company seek in its industry?

1. Major function to be performed.

2. Specialization vs. diversification of activities.

3. Quality or price level sought.

4. Size of operation.

B. Does the firm want to emphasize stability or dynamics, i.e. what is its disposition toward change?

1. Progressiveness - the seeking of better ways.

2. Aggressiveness - drive in making changes.

3. Willingness to take risks.

4. Willingness to share ownership control.

C. What kind of a business citizen does the firm want to be, i.e. what is its social philosophy?

1. Community relations.

2. Government and economic responsibilities.

3. Customer service.

4. Supplier contact.

5. Stockholder relations.

6. Competitor contact.

7. Regard for employees.

D. What type of administration is desired, i.e. what is its management philosophy?

1. Centralization vs, decentralization of decision making.

2. Quality of key personnel.

3. Extent of advance planning and research going into plans.

4. Manner of supervision - strictness of control."

Andere indelingen zijn uiteraard mogelijk en komen voor ${ }^{7}$ ), maar de evenvermelde opsomming doet duidelijk uitkomen welk een grote groep langzicht problemen door een bedrijfsleiding moet worden doordacht en met een besluit afgesloten.

Naar ik meen kan de behoefte aan beleidsconcentratie op een viertal motieven worden teruggevoerd:

1. de zelfhandhaving of continuïteit van het bedrijf;

2. de behoef te om voor ,actualiteitsbeslissingen" te kunnen teruggrijpen op eigen weloverdachte basisoverwegingen en besluiten, waardoor die beslissingen sneller en beter genomen kunnen worden;

3. de noodzaak om subalterne leiders in een geordend geheel algemene aanwijzingen te kunnen geven voor hun doen en laten èn om hun wijze van uitvoering te kunnen beoordelen en controleren èn om te voorzien in hun behoefte aan een aantal vaste uitgangspunten voor hun arbeid;

4. de beoordeling van de eigen taakvervulling.

Ogenschijnlijk zijn de onder $2 \mathrm{t} / \mathrm{m} 4$ genoemde motieven afgeleid van het eerste motief. Dit is inderdaad voor het vrije, onder concurrentieverhoudingen le-

$\left.{ }^{6}\right)$ W. H. Newman, "Business policies and management", Ohio 1953, derde druk, blz. 743 e.v.

7) 1. D. H. Fenn Jr bijv. vat in het boek "Management in a rapidly changing economy" (London 1958) een aantal lange termijn vraagstukken samen onder a. Forces that are shaping the future, b. Basic tools for the manager of tomorrow, c. Personal planning in an era of change.

2. G. Copeman geeft in zijn boek "The role of the managing director" (London 1959) in het hoofdstuk "Determining fundamental policies" verschillende uitgewerkte voorbeelden van bedrijfsbeleid.

ma b blz. 252 
vend, bedrijf het geval. Bij een monopolistisch overheidsbedrijf daarentegen ontbreekt veelal de problematiek van de zelfhandhaving, maar houden de motieven $2 \mathrm{t} / \mathrm{m} 4$ hun gelding. Ter nadere toelichting van de genoemde motieven moge het volgende dienen.

Ad 1. Wat de zelfhandhaving van een bedrijf aangaat, deze is afhankelijk van zijn aanpassing aan de vele wisselende omstandigheden. Snelheid en intensiteit van verandering zijn op de voorgrond tredende kenmerken van de hedendaagse wereld, waarin een bedrijf moet opereren. Op het in 1960 gehouden XIIe CIOSCongres trok A. K. Watson de aandacht met een opsomming van een groot aantal maatschappijen, die in de eerste helft van deze eeuw tot de belangrijkste bedrijven in de V.S. behoorden en sindsdien door gebrek aan aanpassingsvermogen van het toneel zijn verdwenen.

De ,survival” van een bedrijf wordt bepaald door het vermogen van de leiding om:

a. waar te nemen wat zich in de buitenwereld met betrekking tot haar bedrijf voltrekt, in het bijzonder wat aangaat de toekomst;

b. weloverwogen vast te stellen welke aanpassing zich in het bedrijf moet voltrekken om met deze toekomstige ontwikkeling in de pas te blijven lopen;

c. deze noodzakelijke aanpassingen te realiseren.

De factoren a en $b$ zien op het beleid, terwijl de derde factor betrekking heeft op de uitvoering.

Ernest Dale geeft in zijn studie "Contributions to Organization and Administration by Alfred P. Sloan, Jr, and G. M." ${ }^{8}$ ) een goed inzicht hoe de General Motors Cy in 1921 onder leiding van zijn overigens begaafde stichter W. C. Durant was vastgelopen door diens onvoldoende inzicht in de noodzakelijke en weloverwogen aanpassing naar binnen en naar buiten van dit snel gegroeide bedrijf. Dit gebrek aan inzicht komt in een nutshell naar voren in het gesprek tussen Durant en Chrysler, toenmaals diens medewerker, zoals door laatstgenoemde weergegeven:

"A number of arguments on matters of that kind occurred during our three years together. I remember I went to see him once and said, "Billy, for the love of - please, now, say what your policies are for General Motors. I'll work on them; whatever they are, I'll work to make them effective. Leave the operations alone (cursivering van mij, $\mathrm{Rd}$.); the building, the buying, the selling and the men - leave them alone, but say what your policies are."

Billy laughed at me. "Walt, I believe in changing the policies just as of ten as my office door opens and closes."

Een ander bekend voorbeeld, eveneens uit de dynamische wereld van de autofabrikanten, betreft de Ford Motor Cy, die ondanks een enorm potentieel aan kapitaal en mankracht na de laatste wereldoorlog bijna te gronde was gegaan door onvoldoende beleidsvernieuwing.

Ook in ons land zijn verschillende voorbeelden aan te wijzen van bedrijven, die door onvoldoende vooruitzien de tijdige aansluiting aan nieuwere ontwikkelingen hebben gemist.

8) Ernest Dale, “The great organizers" (New York 1960), blz. 71 e.v.

$\mathrm{ma} \mathrm{b}$ blz. 253 
Ad 2. Het terug kunnen grijpen op een vroeger zorgvuldig vastgestelde gedragslijn is een sterk levende behoefte bij tal van bedrijfsleiders. Te veel beslissingen van grote draagwijdte moeten in een haastig tempo en in een confuse atmosfeer worden genomen, waardoor de consequenties onvoldoende kunnen worden overzien. Een goede beleidsvorming, die zich ten aanzien van belangrijke bedrijfsproblemen richt op "answering in advance", kan dit in een groot aantal gevallen voorkomen.

Ad 3. Ook subalterne leiders hebben de behoefte aan een weloverwogen vaste achtergrond in hun werk. De klachten van personeel over gebrek aan een duidelijke gedragslijn vanwege de bedrijfsleiding, zoals die blijken uit allerlei onderzoekingen, zijn legio.

Naar aanleiding van een door hem geleid onderzoek bericht Elliott Jaques ${ }^{9}$ ): "Employees considered they were given insufficient information by top management about company policy, and this had lead to a growing belief that in fact there was no coherent policy. The feeling was strong that management was frequently taking up new ideas and dropping them, leaving the concern a graveyard of unfinished jobs."

Een duidelijke formulering van de doelstellingen en de daarbij te volgen gedragslijn vermindert voorts de weerstand tegen de veranderingen, die men ook in leiding gevende echelons aantreft.

J. G. March en H. A. Simon ${ }^{10}$ ) merken terzake op: "The greater the clarity of goals associated with an activity the greater the propensity to engage in it."

Het is een oude waarheid - Harrington Emerson bijv. stelde in zijn "The twelve principles of efficiency" (New York 1921) reeds: "The first principle is a clearly defined ideal" -, maar waarnaar nog steeds weinig geleefd wordt.

Ad 3 en 4 . Tenslotte is het voor het inzicht in en de controle op de eigen taakvervulling en die van ondergeschikten noodzakelijk, dat er bepaalde essentiële uitgangspunten en normen zijn, waarop teruggegrepen en bijgestuurd kan worden. De aandacht wordt er nu reeds op gevestigd, dat het hierbij niet of niet alleen om financiële verantwoording en verantwoordingsplicht gaat.

\section{Het wezen van het bedrijfsbeleid nader beschoured}

Hierboven werd gesteld, dat beleid betrekking heeft op activiteiten, die verband houden met de basisdoelstellingen, - gedragslijnen en - directieven van het bedrijf. $\mathrm{Er}$ is verschil in basisdoelstellingen en basisgedragslijnen. Wanneer bijv. besloten wordt een geheel andere categorie produkten te fabriceren dan tot nu toe gebruikelijk, dan is er sprake van een andere doelstelling. Wordt daarbij besloten andere dan de bestaande verkoopkanalen te gebruiken, dan is er sprake van een wijziging of een gedeeltelijke wijziging van een gedragslijn.

Nader omschreven omvat beleid:

a. de bezinning op de bestaande doelstellingen van het bedrijf;

b. het opsporen van mogelijk nieuwe doeleinden en het overwegen van hun consequenties;

9) Elliott Jaques, "The changing culture of a factory", (London, Tavistock Publications, 1951), blz. 33. Het belangwekkende onderzoek van Jaques betreft The Glacier Metal Company Ltd. Sinds kort heeft ook de leider van dit bedrijf zijn overdenkingen te boek gesteld.

Zie Wilfred Brown, "Exploration in management" (London 1960). Hij hanteert, evenals trouwens Jaques, policy vaak in de meer beperkte zin van interne gedragsregels.

10) J. G. March en H. A. Simon, "Organizations" (New York 1958), blz. 185.

$\mathrm{m}$ a b blz. 254 
c. het maken van de keuze uit de alternatieve mogelijkheden en daarmede het vaststellen van de doeleinden;

d. bezinning op de wijze waarop in grote lijnen de gewijzigde of nieuwe doelstellingen gerealiseerd moeten worden;

e. het maken van de keuze uit de alternatieve mogelijkheden te dien aanzien en de vaststelling ervan.

De realisatie van de vastgestelde doeleinden en de daarbij te volgen gedragslijn, die kwantitatief veruit het grootste deel der bedrijfsactiviteiten omvat, kan dan in dit verband als uitvoering worden gezien.

Aan het begrip beleid in evenbedoelde zin is toekomstgerichtheid inhaerent. Beleid is ,,vanuit het heden vorm geven aan de toekomst". ${ }^{11}$ ) Beleid kan als het meest essentiële element van het leiding geven gezien worden. Dit betekent allerminst dat de uitvoering en het uitvoeringsapparaat onbelangrijk zijn. Integendeel, er kunnen bovendien in het leven van een bedrijf perioden zijn waarin het accent tijdelijk mede of bijna uitsluitend op de uitvoering en de versterking daarvan moet komen te liggen. Bovendien is een goed uitvoeringsapparaat van veel waarde voor de beleidsvorming, maar gegeven een uitvoeringsapparaat van redelijke kwaliteit komt het primaat toe aan het beleid.

Het is een misverstand te menen, dat beleidsconcentratie alleen van belang is voor grotere bedrijven. Ook voor de kleinere bedrijven is het toetsen van de doeleinden en de realisatiemethodiek aan de zich wijzigende omstandigheden noodzakelijk. Door verschillende omstandigheden komt de aandacht voor bedrijfsbeleid daar echter nog meer dan in het grote bedrijf in gedrang. In de talrijke uitstekende inleidingen over "management problems of small business" op het XIIe CIOS-Congres komt dit naar voren, o.a. blijkende uit het volgende citaat:

"Thus, one of the major problems faced by the owner of a small business is, first, to distinguish between operation and administration and, second, to spend enough time at the administration of his business to provide a sound basis for the future continuity of profitable operations."

Wat de beslissingen of directieven aangaat, deze komen meestal als het ware van zelf als het slotstuk van het beraad over doelstellingen en gedragslijnen. Een enkele maal wordt concrete actie uitgesteld, omdat het getij voorshands niet gunstig geacht wordt.

Het maken van de beslissende keuze uit de alternatieve mogelijkheden wordt door velen aangezien als het eigenlijke kenmerk van de centrale leiding. Wanneer men als maatstaf voor de bepaling van de rangorde van leidende functionarissen de initiërende beslissing neemt, dan is dit juist. Neemt men echter de totale werkzaamheid van de centrale leiding, kwantitatief en $\mathrm{kwalitatief,} \mathrm{in} \mathrm{ogenschouw,} \mathrm{dan}$ zijn de hierboven vermelde factoren $a, b$ en d evenzo belangrijk. In deze werkzaamheid kan in het bijzonder het voor de aanpassing zo uiterst belangrijke creatieve, ideeënrijke en visionaire element van het hoogste echelon naar voren komen. Het is daarop weer, dat in eerste aanleg de mogelijkheid tot het maken en doorzetten van nieuwe combinaties in de Schumpeteriaanse zin berust. De hierbij tot gelding komende realistische fantasie is van het grootste belang voor het adaptatievermogen van het bedrijf en zijn duurzame zelfhandhaving. Uit en in het beraad

11) J. A. A. van Doorn en C. J. Lammers, „Moderne sociologie”, blz. 193. Dit is een voortreffelijk en zeer leesbaar werk (Pocket-uitgave Het Spectrum, Utrecht 1959).

$\mathrm{m} \mathrm{a} \mathrm{b}$ blz. 255 
over deze problematiek dienen, gelijk reeds opgemerkt, de beslissingen zich vaak uiteindelijk a.h.w. vanzelf aan. Tijdige en duidelijke beslissingen van de centrale leiding zijn een conditio sine qua non voor een goede bedrijfsvoering, maar ze zijn niet wat uitsluitend de $\mathrm{k}$ waliteit van de leiding bepaalt. Het is overigens moeilijk vast te stellen welke van de beide elementen "problem solving" en "decision taking" de hoogste eisen aan de bedrijfsleiding stellen; afhankelijk van de situatie is er m.i. van een wisselende prioriteit sprake, met dien verstande, dat het creatief beradende overleg van het "problem solving" vermoedelijk toch het belangrijkst is.

Het hierboven door Watson vermelde feit, dat de laatste 50 jaar tal van bekende ondernemingen van het toneel zijn verdwenen, wijst er op dat ook vroeger het beleidselement een factor van betekenis was. Het heeft echter thans een veel groter gewicht gekregen omdat het bestuursorganisme van het bedrijf en de maatschappij waarin het moet opereren oneindig veel gecompliceerder, dynamischer en veeleisender zijn geworden dan nog maar dertig jaar geleden. Daarbij komt, dat de capaciteiten en/of de werkwijze van leidende functionarissen zich nog zeer onvoldoende aan de nieuwe situatie hebben aangepast. Een op beleidsconcentratie afgestemde organisatiestructuur, bepaalde beleidsvormingsmethodieken en hogere kadervorming zijn de eerste stappen op weg naar een betere harmonisatie van wensen en mogelijkheden ten aanzien van beleidsconcentratie door de hoogste leiding van een bedrijf.

Al is beleidsvorming het essentiële element van het hoogste bedrijfsbestuur, toch geschiedt zij niet exclusief in en door de centrale leiding. Staf en operationele leiders zullen niet alleen, maar moeten met de hoogste directie meedenken in de evaluatie van de bestaande doelstellingen en het realisatiebeleid daarvan en hun aandeel bijdragen in het onderkennen van nieuwe tendenzen en mogelijkheden voor het bedrijf. Elk echelon onder de centrale leiding is belast met beleidsinterpretatie, maar in de hogere echelons zal ook bijgedragen worden in bezinning op vernieuwing en aanpassing van het bestaande beleid. Spel en tegenspel zijn in deze noodzakelijk.

Lettende op dit interdependente verband heeft Prof. Dr H. A. Hutte, zij het in een wat andere samenhang, gesproken van organische beleidsbepaling. ${ }^{12}$ )

Een bijzondere plaats nemen de staforganen in. Prof. Limperg heeft het begrip staf omschreven als de instantie, ,die de uitvoering projecteert, de plannen beraamt, voorlichting geeft, controleert en omgekeerd de leiders inlichtingen verschaft".

Men kan de stafwerkzaamheden onderscheiden in die, welke gericht zijn

1. op een bijdrage in de beleidsvorming,

2. op de uitvoering,

3. op evaluatie en controle.

Op evaluatie van en controle op het beleid hoop ik in een afzonderlijk artikel terug te komen. Voor de onderhavige beschouwing zijn de onder 1 en 2 vermelde staf werkzaamheden, dus die welke betrekking hebben op beleid en uitvoering, van belang.

12) Prof. Dr H. A. Hutte, „Ontwerp voor een Nederlandse arbeids-sociatrie” in het maandblad "Mens en Onderneming" van september 1960 e.v. De betreffende serie artikelen is ook van belang voor bedrijfseconomen-organisatiedeskundigen.

$\mathrm{m}$ a b blz. 256 
Die welke gericht zijn op het beleid houden zich overwegend bezig met een of meer aspecten van de toekomstige ontwikkelingen in vergelijking met de bestaande doelstellingen en gedragslijnen, alsmede met het geven van de algemene uitvoeringsvoorschriften, nadat het beleid is vastgesteld. De andere richten zich in de eerste plaats op de regeling en verbetering van de bestaande uitvoering. De laatste moeten daarom zo dicht mogelijk aan de uitvoering zijn gehecht en lenen zich in het bijzonder voor decentralisatie. In de praktijk komen in talrijke staforganen beleids- en uitvoeringswerkzaamheden dooreengemengd voor, veelal ten nadele van de beleidsarbeid.

Doordat het beleidsberaad in de hoogste leiding zo'n belangrijke plaats inneemt ziet men deze arbeid wel aangeduid als constituerend. Dit is m.i. niet geheel juist. De hoogste leiding neemt nl., gelijk opgemerkt, aan het einde van haar beraad beslissingen, terwijl staforganen hun beraad en onderzoek afsluiten met een advies. Voorzover beider arbeid beradend is, is er voorts nog een zeer belangrijk verschil in karakter. Stafarbeid is, zeker in het grootbedrijf, over meerdere organen en functionarissen verbijzonderd. $\mathrm{Zij}$ heeft daardoor betrekking op een deel van de totale bedrijfsactiviteiten en is dus min of meer specialistisch van aard. De centrale leiding daarentegen beziet de onderscheidene specialistische adviezen en ideeën in hun samenhangend verband, waarbij zij er door haar eigen kennis en ervaring iets aparts aan toevoegt. Haar beraad heeft derhalve een gedespecialiseerd of ,generalistisch" karakter. ${ }^{13}$ )

Het karakter van de werkzaamheden van topstafspecialisten mag dus niet zonder meer op één lijn worden gesteld met dat van de centrale leiding.

De beleids-staf is, in het algemeen, beradend-adviserend en specialistisch. De arbeid van de hoogste leiding daarentegen is beradend-beslissend en generalis$t i s c h$. Het feit, dat binnen de centrale leiding verbijzonderingen plaatsvinden naar kennis, ervaring en capaciteiten doet aan deze laatste karakterisering niets af. Ook die verbijzonderde functies vertonen bedoeld kenmerk.

Beleid valt uiteen in of is opgebouwd uit deelbeleiden. Leiders van beleidsstaforganen en operationele eenheden (inclusief zgn. hulpdiensten) leiden hun beleidsvorming en plannen af van het centrale beleid, aan de vorming waarvan zij echter indirect weer deel hebben. $\mathrm{Er}$ is daardoor in feite naast het algemeen beleid een financieel, een personeels, een technisch, een speurwerk, een commercieel beleid, enz., met dien verstande, dat al deze deelbeleiden ondergeordend zijn, althans dienen te zijn, aan het totale beleid. Voorzover in de praktijk aandacht aan beleidsvorming wordt geschonken richt zich dit vaak tot een of enige onderdelen, bijv. commerciële en financiële vraagstukken. In enkele gevallen ziet men het technisch beleid prevaleren ${ }^{14}$ ), maar vaak wordt aan dit beleid juist nauwelijks aandacht geschonken. ${ }^{15}$ )

13) De woorden gedespecialiseerd en generalistisch zijn m.i. niet fraai; ik weet echter geen betere.

14) Cyril C. Gee, "The structure and future prospects of the electronicbased industries in the United Kingdom", blz. 34. "Too many men at the top at the moment - especially in the older instrument firms - have their heads in the board-room, but their hearts in the laboratory. They have failed to reconcile their interests, and have not kept sufficiently in touch with modern trends in business administration."

15) $\mathrm{Zie}$ „Enige economische en sociale aspecten van de automatisering”, uitgave van het NIVE, blz. 29 e.v. De daar genoemde studie van Dr W. T. Kroese, „De Westeuropese katoenindustrie in de kentering der tijden" (bijlage van E.-S. B van 25 seprember 1957) geeft van de gevolgen en de gevaren van het verwaarlozen van "technisch beleid" een goed voorbeeld.

m a b blz. 257 
Het kan een belangrijke taak van een president-directeur zijn om er op te letten, dat alle belangrijke onderdelen van het bedrijfsbeleid tot hun recht komen. Er van uitgaande dat beleid gericht is op aanpassing door en aan nieuwe mogelijkheden, houdt dit dan in dat voor een goed beleid technisch-chemische uitvindingen en een daarop verbijzonderd apparaat noodzakelijk zijn? Naar ik meen niet altijd. De vernieuwing en aanpassing van de doelstellingen en de gedragslijn kunnen zich in vele gevallen zeer wel zonder eigen uitvindingen voltrekken. Speurwerk is niet voor alle bedrijven, die daarvoor in beginsel in aanmerking komen, noodzakelijk, wel vaak ontwikkeling, d.w.z. aanpassing van de uitvindingen van anderen aan de bestaande produkten en produktiemethoden van het bedrijf. "Innovation" is niet altijd afhankelijk van "invention". ${ }^{16}$ ) Een en ander wil evenwel niet zeggen, dat voor bepaalde bedrijven fundamentele en basis research niet van groot belang zijn voor de aanpassingsmogelijkheden, in het bijzonder voor het verkrijgen van een voorsprong in de aanpassingswedloop. Vooral voor het zeer grote bedrijf kan het noodzakelijk zijn in omvangrijke mate aan speurwerk te doen. „Wij blijven”, staat in het jaarverslag 1960 van Philips vermeld, „voortdurend aandacht schenken aan de vernieuwing en aanvulling van onze produktenreeks. De researchactiviteit is daarbij van fundamentele betekenis. Uit de hiernavolgende verslagen van de hoofdindustriegroepen blijkt dat door de arbeid in de research- en ontwikkelingslaboratoria nieuwe artikelen op de markt konden worden gebracht, voortgaande verbeteringen van bestaande produkten konden worden bereikt en grotere efficiency in de produktie tot stand kwam."

In dit verband wordt opgemerkt, dat er vaak verkeerd beleid wordt gevoerd door onvoldoende evenwicht na te streven tussen speurwerk, ontwikkeling en marktonderzoek. W. Travers Jerome vermeldt, dat volgens het U.S. Department of Commerce acht van de tien nieuw ontwikkelde produkten mislukkingen zijn gebleken, vermoedelijk door het feit dat ongeveer zes maal zoveel voor product development als voor market development is besteed. ${ }^{17}$ )

Tenslotte een opmerking over de "intangibles" van het bedrijfsbeleid. Er zijn bepaalde immateriële normen - de mate van eerlijkheid en openheid, de sociale instelling, de houding tegenover concurrenten, e.d. -, die vaak moeilijk onder woorden zijn te brengen en toch tot de basisgedragslijn van een bedrijf kunnen behoren. Hoewel zij in contacten met een bedrijf soms duidelijk voelbaar zijn, zijn deze min of meer ethische achtergronden niet altijd bevredigend te formuleren. Vaak worden zij alleen levend en voor overdracht vatbaar door het voorbeeld van de leiders.

\section{\4. Het ,inbouwen" van beleidsconcentratie}

Geeft men zich rekenschap 1. van de veelheid en genuanceerdheid van beleidsonderwerpen, 2. van het feit, dat ook de problemen aan de uitvoering verbonden

$\left.{ }^{16}\right)$ Over de betekenis en problematiek van speurwerk, ook in verband met bedrijfsbeleid, zijn door de Engelse economen C. F. Carter en B. R. Williams een drietal uitstekende studies geschreven, resp. "Industry and Technical Progress" (London 1957), "Investment in Innovation" (London 1958) en "Science in Industry" (London 1959). Zij verlenen hun bijzondere waarde mede aan het feit, dat zij gebaseerd zijn op onderzoek bij 250 bedrijven, gespreid naar de voornaamste in. dustrieën, verschillende bedrijfsgrootten, vormen van eigendom en graad van vooruitstrevendheid.

${ }^{17)}$ W. Travers Jerome, "Executive control - The catalyst" (New York, London 1961), blz. 79. 
vele en tijdrovend zijn en 3 . dat de naoorlogse, bijna ononderbroken groeieconomie leiders van bedrijven bijna geen tijd laat om op adem te komen, dan is het duidelijk dat er voorzieningen nodig zijn, die zich richten op de zekerstelling van de beleidsconcentratie.

Zoals in een volgend artikel nader zal worden uiteengezet is het door een combinatie van verschillende voorzieningen mogelijk a.h.w. zekerheden voor beleidsconcentratie in te bouwen. Maatschappelijk gezien zag Schumpeter aanvankelijk die zekerheid uitsluitend belichaamd in wat hij de ondernemer noemde, de man, die "neue Kombinationen durchsetzt”. Een bedrijfsleider die geen nieuwe combinaties doorzet, noemde hij toen een statisch beheerder, een "Wirt"; de expansieve dynamische bouwer daarentegen een „Unternehmer”. ${ }^{18}$ ) Er zijn twee typen van „Wirtschaftssubjekte”, schreef hij, „Wirte schlechtweg und Unternehmer”. Nieuwe combinaties, zo zette hij voorts uiteen, zijn voor de ondernemer evenwel niet aan de orde van de dag. Slechts enige malen in zijn leven vervult een ondernemer de werkelijke ondernemersfunctie. In zijn voorlaatste grote werk "Capitalism, Socialism, and Democracy" ${ }^{19}$ ) staat hij in het hoofdstuk "The obsolescence of the entrepreneurial function" stil bij wat hierboven genoemd is het inbouwen van beleidsconcentratie in de onderneming. Hij ziet daardoor de ondernemersfunctie tot routine worden, zijn oorspronkelijk karakter verliezen en daarmede de ondernemer oude stijl in feite verdwijnen.

"We have seen that the function of entrepreneurs is to reform or revolutionize the pattern of production by exploiting an invention or, more generally, an untried technological possibility for producing a new commodity or producing an old one in a new way, by opening up a new source of supply of materials or a new outlet for products, by reorganizing an industry and so on. Railroad construction in its earlier stages, electrical power production before the First World War, steam and steel, the motorcar, colonial ventures afford spectacular instances of a large genus which comprises innumerable humbler ones - down to such things as making a success of a particular kind of sausage or toothbrush. This kind of activity is primarily responsible for the recurrent "prosperities" that revolutionize the economic organism and the recurrent "recessions" that are due to the disequilibrating impact of the new products or methods. To undertake such new things is difficult and constitutes a distinct economic function, first, because they lie outside of the routine tasks which everybody understands and, secondly, because the environment resists in many ways that vary, according to social conditions, from simple refusal either to finance or to buy a new thing, to physical attack on the man who tries to produce it. To act with confidence beyond the range of familiar beacons and to overcome that resistance requires aptitudes that are present in only a small fraction of the population and that define the entrepreneurial type as well as the entrepreneurial function. This function does not essentially consist in either inventing anything or otherwise creating the conditions which the enterprise exploits. It consists in getting things done.

This social function is already losing importance and is bound to lose it at an accelerating rate in the future even if the economic process itself of which entrepreneurship was the prime mover went on unabated. For, on the one hand, it is much easier now than it has been in the past to do things that lie outside familiar routine - innovation itself is being reduced to routine. Technological progress is increasingly becoming the business of teams of trained specialists who turn out what is required and make it work in predictable ways. The romance of earlier commercial adventure is rapidly wearing away, because so many more things can be strictly calculated that had of old to be visualized in a flash of genius."

Aan de sociologische aspecten van dit verschijnsel, waar het Schumpeter vooral

18) Joseph Schumpeter, "Theorie der wirtschaftlichen Entwicklung" (München und Leipzig, 1926), blz. 110 e.v.

19) Joseph Schumpeter, "Capitalism, Socialism, and Democracy", vierde druk, London 1954, blz. 132 e.v.

$\mathrm{m}$ a b blz. 259 
om te doen is, ga ik hier voorbij. Wel lijkt het mij van enig belang om in te gaan op de vraag in hoeverre het inbouwen of de institutionalisering van beleidsconcentratie het leiding geven tot een onpersoonlijke routinearbeid maakt. Naar ik meen behoeft dit juist wat het beleidsaspect betreft niet altijd het geval te zijn.

De ervaring wijst uit, dat in het creëren, beoordelen en kiezen met betrekking tot de alternatieve mogelijkheden in doelstellingen en gedragslijnen vaak sterk persoonlijke accenten tot gelding komen. Zo zelfs, dat men ondernemingen in dezelfde branche tot geheel andere keuzen ziet komen. ${ }^{19 \mathrm{a}}$ )

Afgezien hiervan moet bedacht worden, dat in het kleinere en middelgrote bedrijf het persoonlijke en creatieve van de leider een uiterst belangrijke rol speelt. En al is deze groep vrijwel overal relatief achteruit gegaan door de toeneming van het grootbedrijf, $\mathrm{kwantitatief}$ is zij toch nog van grote betekenis.

Voorts dient m.i. niet uit het oog te worden verloren, dat de scheiding van beleid en uitvoering waardoor de hoogste leiding van de meest routineachtige werkzaamheden wordt ontlast, juist de gelegenheid om meer persoonlijk getinte „,neue Kombinationen" uit te denken en door te zetten, kan vergroten.

Op de betekenis van het persoonlijk element bij de beleidsvorming wordt overigens nog later teruggekomen.

March en Simon ${ }^{20}$ ) waarderen de ,institutionalization of innovation" aanmerkelijk positiever dan Schumpeter door er op te wijzen, dat juist daardoor het ge. hele bedrijf met vernieuwing en vernieuwingsprocessen vertrouwd raakt, waardoor de weerstand tegen de daaruit voortvloeiende veranderingen vermindert.

"It should be possible to distinguish the patterns of innovation of organizations that have institutionalized the innovative process in one way or another from those that have not. For example, we would expect the rate of innovation to be less sensitive to environmental changes in the former than in the latter. On the whole, at least under conditions of a relatively stable environment, we would also expect the average rate of innovation to be higher the greater the institutionalization of innovation."

\section{Beleid komt niet voor in ,reincultuur"}

In een aantal bedrijven is thans een duidelijk streven waarneembaar om tot vormen van beleidsconcentratie te komen. Toch lukt het de doorsnee leiding vrijwel nimmer om tot een volledige „beleids”besteding te komen. Er zijn altijd dingen van de dag, waaraan onontkoombaar aandacht moet worden besteed. Het is al een hele prestatie wanneer een directie een derde van haar tijd voor beleidsvraagstukken weet te gebruiken.

In het bekende tijdschrift „Fortune” (dec. 1955) heeft Perrin Stryker onder de titel "Who is an executive?" een interessante beschouwing gewijd aan facetten van het bedrijfsbeleid, gebaseerd op enquêtes. Uit de 99 definities van praktiserende executives kwamen tezamen niet minder dan 115 "executive actions" naar voren. Nader geanalyseerd blijkt het algemeen beeld - the self portrait noemt Stryker het - als volgt beschreven te kunnen worden:

19a) In een gesprek met Ir M. H. Lubbers van N.V. Philips' Gloeilampenfabrieken over dit onderwerp merkte deze op, dat hij bij de grote producenten van electrische/electronische artikelen e.d. meende te hebben waargenomen, dat de produktieprogramma's, op !angere termijn gezien, wel een sterke gelijkenis vertonen. Vermoedelijk door research, produktie en distributie verwantschap.

20) J. G. March en H. A. Simon, "Organizations" (New York 1958), blz. 184 en 185. Zij noemen als voorbeeld van innovation de activiteiten van "a research and development department", maar in feite is het begrip innovation bij hen ruimer.

$\mathrm{m}$ a b blz. 260 
"An American executive is a person paid for a full-time job in which he:

1) directly helps to set his company's objectives and over-all policies; 2) is required to make or approve decisions that significantly affect profits and future plans; 3 ) coordinates several major corporate functions, or those of a major division or department; 4) maintains and develops an organization of trained subordinates to achieve the company's objectives; and 5) delegates responsibility and authority to the organization, and controls performance and results through at least one level of supervision."

\section{Hun relatieve positie zien deze leiders zelf aldus:}

"1. Only "a few at the top" in any company really function as executives.

2. An executive operates on a higher level than a manager; and the positions of superintendent and supervisor generally rank below manager.

3. The carrying out of policies set by others is the function of managers; indeed, this is one of the clearest distinctions that corporation presidents generally make between their own functions and the jobs performed by those below the executive level.

4. The two actions most distinctively characteristic of the executive are setting company-wide policy and making major decisions; and the executive job is an inseparable combination of these and other functions."

Uit deze verkenning blijkt duidelijk, dat de leiders van de betreffende grootbedrijven zich van het wezen en het primaat van beleidsvorming bewust zijn. Evenzeer blijkt er echter uit, dat de beleidsactiviteiten met andere activiteiten zijn verbonden.

Daarbij moet echter wel bedacht worden, dat beleidsvorming nog een proces in wording is en dat over tien jaar de overige werkzaamheden verhoudingsgewijs wel eens aanmerkelijk minder kunnen blijken te zijn.

Het betreffende onderzoek geeft geen kwantitatieve verdeling van de tijdsbesteding voor beleids- en andere activiteiten. Enige aanwijzing daaromtrent is wel te vinden in de resultaten van een door de universiteit van Minnesota ingesteld onderzoek naar de tijdsbesteding van de "typical executive-manager", waaronder te verstaan valt zowel de president als de overige leden van de directie. ${ }^{21}$ ) Het blijkt, dat de wekelijkse werktijd ongeveer 47 uren bedraagt en als volgt besteed wordt:

\begin{tabular}{lrr} 
planning & 9 uur & $19 \%$ \\
supervising & 12 uur & $26 \%$ \\
coordinating & 7 uur & $15 \%$ \\
evaluating & 6 uur & $13 \%$ \\
investigating & 5 uur & $11 \%$ \\
negotiations & 5 uur & $11 \%$ \\
staffing & 2 uur & $4 \%$ \\
representing & 1 uur & $2 \%$ \\
\cline { 2 - 3 } & 47 uur & $101 \%$
\end{tabular}

Wanneer planning gelijk gesteld wordt aan lange termijn beleidsvorming, hetgeen niet geheel juist is en waaraan nog nader aandacht zal worden besteed, dan wordt prima vista $19 \%$ van de tijd aan beleidsvorming besteed. Het is evenwel mogelijk dat op de keper beschouwd in supervising, coordinating, evaluating en investigating ook nog beleidsvormende arbeid begrepen is. Misschien ook in negotiations en staffing. Men kan niet a priori stellen dat deze werkzaamheden niet in een beleidsdirectie thuis horen. Wel nemen zij vermoedelijk een te groot deel van

21) Maynard e.a., "Top management handbook" (New York 1960), artikel van G. L. Carpenter, "The president's job", blz. 171. 
de tijd in beslag doordat zij ten dele betrekking hebben op onderdelen van de uitvoering. Zonder nadere gegevens is te dien aanzien echter geen goed oordeel te vormen. Wanneer bijv. een directie van een betrekkelijk kleine onderneming uit een relatief groot aantal leden bestaat zal het logisch gevolg zijn, dat zij meer uitvoeringswerkzaamheden verricht. Alles bijeen wekken echter de gegeven cijfers m.i. de indruk, dat in verhouding nog te weinig tijd aan werkelijke beleidsvorming wordt besteed.

De hierboven vermelde studie van Sune Carlson ${ }^{5}$ ), hoewel veel feitelijk materiaal behelzend, geeft geen aanwijzing omtrent de besteding naar beleid en uitvoering, omdat zij zich richtte op "the immediate goals which the executives were striving towards" (blz. 117). Gezien zijn hierboven op blz. 251 vermelde uitlating zou die voor policy, ware zij geregistreerd geweest, waarschijnlijk bijzonder laag gebleken zijn.

\section{$\int 6$. Het begrip ,hoogste leiding" in verband met beleidsvorming nader be- schoured}

In het bovenstaande $(\$ 1)$ is uitgegaan van het ongedeelde begrip hoogste leiding. In feite bestaat de hoogste leiding veelal uit verschillende groepen en/of functionarissen. In de Nederlandse naamloze vennootschappen kan met betrekking tot de beleidsvorming te dien aanzien worden onderscheiden de (algemene vergadering van) aandeelhouders, de (raad van) commissarissen, de president-directeur en de overige directeuren. In beschouwingen over beleidsvorming vindt men weinig of geen aandacht besteed aan de aandeelhouders; m.i. ten onrechte. De formele betekenis van aandeelhouders blijkt reeds uit het feit, dat voor belangrijke afwijkingen van de oorspronkelijke doelstellingen soms statutenwijzigingen nodig zijn. In de algemene vergadering van aandeelhouders van de kleine en middelgrote familievennootschappen, maar soms ook van open vennootschappen vinden voorts meer dan eens beleidsdebatten annex -besluiten plaats.

De raad van commissarissen is, of althans kan zijn, een belangrijk beleidsorgaan. Het hangt o.a. van de grootte van de bedrijven, de in de statuten aan commissarissen toegekende bevoegdheden en de feitelijke omstandigheden, w.o. hun capaciteiten en hun verhouding tot de directie, af in welke mate zij beleidsvormend werken. In die gevallen dat directies te zeer gebonden zijn aan de dagelijkse leiding kan beleidsvorming een belangrijke functie van commissarissen zijn.

Te bedenken valt voorts, dat in tal van bedrijven commissarissen een beleidsrol van betekenis spelen door het feit, dat zij hun goedkeuring aan belangrijke investeringsplannen moeten geven. Een rol die lang niet altijd uitsluitend van formele aard is.

Soms oefenen nog anderen dan de bovengenoemden invloed uit op de beleidsvorming, bijv. de Staat of bankiers. In het begin van deze eeuw vormden in de V.S. bankiers te dien aanzien een machtige pressure groep, die toen door hun politiek om in zo kort mogelijke tijd zoveel mogelijk uit een onderneming te halen, zeer storend op het beleid van de betreffende bedrijven kon inwerken. Het is minder bekend maar een feit, dat Taylor c.s. zich krachtig tegen de schadelijke invloeden van dergelijke praktijken op een gezond bedrijfsbeleid hebben verzet. Thans zijn het aldaar meer dan eens bepaalde vakverenigingen, die tijdelijk de aanpassing van een bedrijf aan de zich wijzigende omstandigheden belemmeren en daardoor indirect het bedrijfsbeleid mede bepalen.

$\mathrm{m} \mathrm{a} \mathrm{b}$ blz. 262 


\section{Staatsbestuur en beleid}

Het staatsbestuur kent al zeer geruime tijd beleidsconcentratie. De leer van de trias politica, waarbij scheiding gemaakt wordt tussen wetgevende, uitvoerende en rechterlijke macht, had niet de totstandkoming van een specifiek beleidsorgaan tot doel, maar waarborging van de onafhankelijkheid van de drie genoemde machten ten opzichte van elkaar. $\mathrm{Zij}$ had echter als nevengevolg, dat de wetgevende macht tot beleidsorgaan werd. In ons land kan men de Staten Generaal als de beleidsvormende instantie in ons staatsbestuur zien. ${ }^{22}$ ) $\mathrm{Zij}$ verrichten geheel de activiteiten omschreven op blz. 255 sub c en e. Ook de ministers verrichten beleidsarbeid, die echter het karakter heeft van initiatief, voorberaad en voorbereiding. Over de belangrijkste zaken beslissen echter, zowel wat de doelstellingen aangaat als de gedragslijn die bij de realisatie daarvan moet worden gevolgd, de Staten Generaal. Zo worden niet alleen de doeleinden van de sociale politiek in wetten vastgelegd, maar ook, in grote lijnen, de wijze van uitvoering, bijv. door de Sociale Verzekeringsbank of door bedrijfsverenigingen.

Ministers zou men in deze, tot op zekere hoogte, kunnen vergelijken met de leidende functionarissen onder een beleidsdirectie, die in de vorm van ideeën, voorstellen, oordelen, enz. hun aandeel in de beleidsvorming leveren en voorts het eenmaal vastgestelde beleid uitvoeren, waarbij een zekere ruimte voor eigen beleidsvaststelling c.q. beleidsinterpretatie bestaat.

De taak van ministers is echter vooral sinds de bevrijding zo omvangrijk en veelsoortig geworden, dat deze bewindslieden nauwelijks tijd hebben om weloverwogen aandacht aan lange termijn problemen te besteden, m.a.w. in de zgn. uitvoerende macht doet zich ook het vraagstuk beleidsconcentratie - uitvoering gevoelen. Een m.i. belangrijk probleem van onze tijd.

De zoeven vermelde scheiding in beleid en uitvoering binnen het staatsbestuur in zijn totaliteit waarborgt overigens niet, dat aan alle belangrijke vraagstukken, bijv. aan de efficiency van het staatsapparaat, daadwerkelijk aandacht wordt besteed.

Ook in de provinciale en gemeentelijke huishouding valt het bovenbedoelde onderscheid tussen beleid en uitvoering te constateren.

22) a. Zie „Nederlands Bestuursrecht” (Alphen a. d. Rijn 1953), Algemeen deel, door Mr A. M. Donner, waaruit de volgende aanhaling (blz. 1):

„Vruchtbaarder is het uit te gaan van het feit, dat alle overheidswerkzaamheid zich op twee verschillende vlakken voltrekt. Het vlak van de doel- of van de taakstelling enerzijds; het vlak van de doelverwezenlijking of taakvervulling anderzijds. Deze vlakken corresponderen met de twee fasen waarin zich de overheidsactiviteit afspeelt.

In de eerste fase wordt bepaald, welke de richting zal zijn, welke het staatsleven heeft te nemen. Men bevindt zich dan in het vlak van de politiek, van de regering in de hoogste zin van dat woord. De tweede fase is die van de tenuitvoerlegging van de in het politieke vlak genomen beslissingen. Men is dan op het vlak van het bestuur, dat niet heeft te beslissen over de vraag, welke richting de ontwikkeling van het staatsleven heeft te nemen, maar dat uitgaande van de dienaangaande genomen beslissingen alles in het werk heeft te stellen om deze te verwezenlijken en uit te voeren. Het bestuur is daarbij niet aan handen en voeten gebonden; het geniet dikwijls een zeer ruime vrijheid. Maar het beleid dat wordt gevoerd is bestuursbeleid en valt qualitatief te onderscheiden van het echte regeringsbeleid."

De terminologie is hier en daar anders, maar de overeenkomst met de begrippen bedrijfsbeleid en uitvoering treffend.

b. Interessante beschouwingen over de werkverdeling binnen de groep van ministers o.a. in Nederland, België, Frankrijk en Engeland vindt men bij E. van Raalte, „De ontwikkeling van het Minister-presidentschap" (Leiden 1954).

$\mathrm{m}$ a b blz. 263 


\section{\$8. Terminologische onderscheidingen met betrekking tot het bedrïfsbeleid}

De laatste decenniën tracht althans in het buitenland ook de bedrijfseconomische wetenschap zijn weg in de problematiek van het bedrijfsbeleid te vinden. In verband daarmede worden verschillende uitdrukkingen gehanteerd. Er zijn schrijvers, die het woord "administration" willen reserveren voor alles wat met policy en policy making te maken heeft; de uitvoering wordt dan aangeduid met "managing". O. Sheldon maakte deze onderscheiding overigens reeds in 1923, waarbij hij voor een zelfde terminologie verwijst naar een verhandeling van $J$. N. Schulze voor de Taylor Society in augustus $1919 .{ }^{23}$ ) Anderen, bijv. Kimball en Kimball ${ }^{24}$ ), zien de relatie juist omgekeerd. Verschillende Angelsaksische schrijvers hanteren het woord "policies" echter ook voor meer gedetailleerde gedragsregels. H. A. Simon suggereert hiervoor de uitdrukking "working policies" te gebruiken, ${ }^{25}$ ) anderen zoeken het in de aanduiding "long term policy" voor het eigenlijke bedrijfsbeleid, hoewel policy of bedrijfsbeleid meestal zonder meer aan lange termijn actie - managing the future - wordt gerelateerd.

In de vorige paragraaf $\mathrm{kwam}$ reeds tot uitdrukking, dat vele Amerikaanse leiders het woord executive min of meer met beleidsvorming identificeren en manager met uitvoering. De tegenwoordig nogal gebruikte uitdrukking management by objectives heeft een wijdere betekenis doordat zij betrekking heeft op de normstelling van alle fasen en geledingen van de uitvoering. ${ }^{26}$ )

Verschillende schrijvers rekenen het beraad en de vaststelling van de doeleinden niet tot het beleid; alleen de te volgen gedragslijn - the general rules of action voor de realisatie van de doeleinden is dan "policy", "policy making" of "policy formulation". ${ }^{27}$ ) Naar mijn mening is deze scheiding evenwel ondoelmatig, omdat in het algemeen beide onderwerpen betrekking hebben op dezelfde personen, dezelfde kennis, dezelfde geestelijke instelling en hetzelfde orgaan; ook in het staatsbestuur (zie $\$ 6$ ) omvat het begrip beleid reeds van ouds beide elementen. Andere auteurs onderscheiden niet voldoende tussen beleid, planning en plannen. ${ }^{28}$ )

In verband met beschouwingen over bedrijfsbeleid komen soms de woorden strategie en taktiek voor. Van Dale definieert strategie als ,,de kunst van oorlogsvoering inzonderheid voorzover deze bestaat in het maken en uitvoeren van plannen voor beweging op grote schaal". Aangaande het krijgsbedrijf kan men stellen, dat de doelstellingen van een oorlog door de regering van een land bepaald worden. Ten dele ook de wijze van effectueren, zoals de keuze van eventuele bondgenoten of wapens, bijv. geen gebruik van gifgas of atoomwapens. Dit in aanmerking nemende zou men de strategie een onderdeel, zij het een uiterst be-

23) O. Sheldon, "The philosophy of management", London 1923, blz. 32.

${ }^{24}$ D. S. Kimball and D. S. Kimball Jr., "Principles of organization", zesde druk, New York 1947, blz. 157 e.v.

25) H. A. Simon, "Administrative Behaviour", tweede druk, New York 1957, blz. 59, "A note on terminology": "Perhaps the ethical premises of management could be called "legislative policy"; the broad non-ethical rules laid down by top management, "management policy"; and other rules, "working policy".

"26) Zie bijv. de definitie van Peter F. Drucker in "The practice of management" (New York 1954), blz. 131: "Management by objectives is the system that enables us to substitute management by self-control for management by domination".

27) Bijv. W. H. Newman in "Business policies and Management" (Ohio 1953), blz. 744.

Petersen and Plowman, "Business Organization and Management" (Chicago 1953) begrijpen daarentegen de doelstellingen wel in het begrip policy (blz. 334).

28) Bijv. H. Koontz en C. O'Donnell in "Principles of Management".

$\mathrm{ma} \mathrm{b}$ blz. 264 
langrijk onderdeel, van de gedragslijn ter realisatie van het beleid kunnen noemen. Houdt men dit in het oog, dan is het begrijpelijk dat sommigen beleid zien als het (opsporen, overwegen en) vaststellen van doeleinden en de strategie om deze te verwezenlijken. ${ }^{29}$ ) De taktiek is de leer van de gevechtsvoering; zij ligt dus meer in het uitvoeringsvlak.

Sommige auteurs onderscheiden tussen policy en policy process. Policy is dan het vastgesteld beleid, policy process het geheel van overwegingen en beraadslagingen, dat daaraan voorafgaat.

De sociologen Lasswell en Kaplan bijv. geven daaromtrent de volgende omschrijving: "Policy is a projected program of goal values and practices; the policy process is the formulation, promulgation, and application of identifications, demands, and expectations concerning the future interpersonal relations of the self." ${ }^{30}$ )

Prof. Dr Th. Limperg Jr onderscheidt, gelijk bekend, drie richtingen, waarin zich de verbijzondering binnen een bedrijf voltrekt, nl. met betrekking tot de onderdelen van de produktiestroom, de leiding van de arbeid en de geografische plaats, met dien verstande, dat elk dezer drie hoofdrichtingen weer in verschillende richtingen uiteen kan vallen.

Ten aanzien van de leiding van de arbeid zijn die deelrichtingen: naar de hiërarchie, de deelbewerkingen van het produkt, de elementen van de geleide arbeid en die van de leidende arbeid. Wat de leidende arbeid aangaat is er een differentiatie in horizontale richting - constitueren, dirigeren en controleren - en een in verticale richting - leiding en uitvoering. De laatste onderscheiding, die hij een categorische onderscheiding noemt ${ }^{31}$ ), berust op het omhoog stuwen van de meerwaardige leiderscapaciteiten en de afstoting van de overige naar beneden. In deze gedachtengang kan men het bedrijfsbeleid tot de verticale differentiatie en de categoriale indeling rekenen en als een voortgang van de opwaartse stuwing van de essentiële elementen van het leiding geven zien.

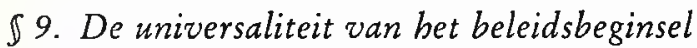

Bij bovenstaande beschouwingen over beleid en uitvoering stond vooral het particulier bedrijf, groot en klein, voor ogen. Het beginsel van de scheiding van deze werkzaamheden heeft echter algemeen gelding voor elke huishouding waaraan een langdurig of een duurzaam bestaan ten grondslag ligt. Het geldt ook voor een overheidsbedrijf, al ziet men door verschillende oorzaken daar weinig aandacht voor het probleem.

29) Zie ook John McDonald, "Strategy in Poker, Business and War", New York 1948, blz. 16.

30) Ontleend aan het bovenvermelde boek van J. A. A. van Doorn en C. J. Lammers, „Moderne sociologie", blz. 335.

31) Ik heb altijd enige moeite met de uitdrukking categorisch, vooral omdat Limperg die tegenover de onderscheiding naar functie stelt. Wanneer men bij het begrip functie denkt aan de werking met betrekking tot het doel kan men m.i. zonder bezwaar leiding en uitvoering als onderscheidene functies zien, omdat zij op verschillende doeleinden betrekking hebben. Categorisch wordt door Van Dale o.a. omschreven als klasse, rang, afdeling, elk der opzichten waarin het bestaande beschouwd kan worden, zoals wezen, plaats, tijd. De Nouveau Petit Larousse is wat duidelijker door te spreken van een onderscheiding "classe d'objets de même nature".

In verband met de behoefte en de noodzaak om verschillende werkzaamheden of groepen van werkzaamheden te onderscheiden acht ik de terminologie categorie, categoriale indeling overigens zeer wel bruikbaar. 
Maar ook buiten de bedrijfs- en overheidshuishouding is de scheiding der genoemde activiteiten van belang. Men zou kunnen zeggen, zij geldt voor elke huishouding van enige omvang en betekenis. Als voorbeeld vermeld ik daartoe onderstaand citaat uit het tijdschrift „Nature” (dd. 18 februari 1961, blz. 518) over "University administration in Great Britain":

"Despite, however, the approval given by Sir Arthur Rucker in his recent report to certain aspects of university administration, there appears to be a prima facie case for an independent examination of the whole structure of university administration in the light of the needs of to-day. Apart from the internal stresses that arise inevitable out of the sheer numerical size of expanding universities, the problems of adjusting the claims of teaching and research, those of research between the different disciplines and fields of knowledge, and particularly the relation between available national resources and what is being done elsewhere, either in other universities or in government or independent research institutions, are growing in complexity. It is already clear that more attention will have to be given to university co-operation, and increasingly the demands of university administration call for the separation of policy and executive management (cursivering van mij. $\mathrm{Rd}$ ). This is not to suggest that a solution is to be found by imparting unmodified the type of organization which characterizes large, efficient and progressive business organizations."

Een en ander betekent, dat voor de problematiek van het bedrijfsbeleid ook vergelijkende studies met overeenkomstige vraagstukken en verschijnselen in andere dan bedrijfshuishoudingen van nut kunnen zijn. Voorshands is dit waarschijnlijk slechts mogelijk voor regeringsbeleid en bedrijfsbeleid, omdat momenteel alleen voor deze beide belangstelling en publicaties bestaan.

Resumerende zijn in de onderhavige beschouwingen in het bijzonder de behoefte aan en het wezen van beleidsconcentratie aan de orde gesteld. In een volgende verhandeling zal aandacht worden besteed aan het verband tussen bedrijfsbeleid, organisatiestructuur, bemanning, beleidsmethodieken, planning, bedrijfsbegroting, beleidsevaluatie en -controle. 